\title{
THE INTERACTION OF ARENICIN-1 WITH C3B COMPLEMENT PROTEIN
}

\author{
E.S. Umnyakova', I.A. Krenev ${ }^{2}$, S.V. Legkovoy ${ }^{2}$, A.V. Sokolov ${ }^{1}$, O.N. Rogacheva ${ }^{2}$, \\ T.V. Ovchinnikova ${ }^{3}$, V.N. Kokryakov ${ }^{1,2}$, M.N. Berlov ${ }^{1}$ \\ ${ }^{1}$ Institute of Experimental Medicine, Saint Petersburg, Russia; \\ ${ }^{2}$ Saint Petersburg State University, Saint Petersburg, Russia; \\ ${ }^{3}$ M.M. Shemyakin and Yu.A. Ovchinnikov Institute of Bioorganic Chemistry, Russian Academy of Sciences, \\ Moscow, Russia
}

\section{ВЗАИМОДЕЙСТВИЯ АРЕНИЦИНА-1 С БЕЛКОМ КОМПЛЕМЕНТА СЗВ}

\author{
Е.С. Умнякова ${ }^{1}$, И.А. Кренев ${ }^{2}$, С.В. Легковой ${ }^{2}$, А.В. Соколов ${ }^{1}$, О.Н. Рогачева ${ }^{2}$, \\ Т.В. Овчинникова ${ }^{3}$, В.Н. Кокряков ${ }^{1,2}$, М.Н. Берлов ${ }^{1}$ \\ ${ }^{1}$ Институт экспериментальной медицины, Санкт-Петербург; \\ ${ }^{2}$ Санкт-Петербургский государственный университет, Санкт-Петербург; \\ ${ }^{3}$ Институт биоорганической химии имени М.М. Шемякина и Ю.А. Овчинникова РАН, Москва
}

\begin{abstract}
The complement system and antimicrobial peptides (AMPs) are known to be vital humoral factors of innate immunity. Earlier we showed the double-sided influence of arenicin-1 (Ar-1), the AMP from a sea polychaeta Arenicola marina, on the complement activation. In this work we studied the binding of Ar-1 to C3b protein, the fragment of the central complement component $\mathrm{C} 3$, using surface plasmon resonance. We also performed molecular docking and molecular dynamics of interaction between $\mathrm{C} 3 \mathrm{~b}$ fragment $-\mathrm{C} 3 \mathrm{c}-$ and $\mathrm{Ar}-1$. All these data showed that the influence of Ar-1 on complement activation might be realized through the interaction with $\mathrm{C} 3 \mathrm{~b}$, the most important component for complement activation. Ar-1 may be used for the design of new complement regulators for treating complement-related diseases.
\end{abstract}

Keywords: complement system; antimicrobial peptides; arenicin-1; C3b protein.

Система комплемента и антимикробные пептиды (АМП) являются важнейшими компонентами врожденного иммунитета. Ранее мы показали разнонаправленное влияние ареницина-1 (Ar-1), АМП из морской полихеты Arenicola marina, на активацию комплемента. В этой работе мы изучали связывание Ar-1 с белком C3b, фрагментом центрального компонента комплемента C3, с помощью поверхностного плазмонного резонанса. Мы также провели моделирование взаимодействия фрагмента $\mathrm{C} 3 \mathrm{~b}-\mathrm{C} 3 \mathrm{c}-$ и пептида Ar-1 с помощью методов молекулярного докинга и молекулярной динамики. Все эти данные дают возможность предположить, что влияние Ar-1 на активацию комплемента может быть реализовано через взаимодействие с C3b, наиболее важным компонентом для активации комплемента. Ar-1 может быть использован для разработки новых регуляторов системы для лечения заболеваний, связанных с комплементом.

Ключевые слова: система комплемента; антимикробные пептиды; ареницин-1; белок С3b.

Introduction. The coevolution and colocalization of complement system and antimicrobial peptides (AMPs) give the opportunity to assume the existence of close interactions between different components of these systems. There are some data about such interactions and consequences of such interplay, including complement modulation [1-5]. But they are not so numerous and some of them are rather contradictory.

The earlier results of our investigations confirm the literature data about the interactions between $\mathrm{C} 1 \mathrm{q}$ and human defensins, tachyplesin-1, arenicin-1 (Ar-1), protegrin-1 form complexes with C1q directly [6]. We also showed that different AMPs possess modulator activity on complement depending on peptide concentrations; in particular, Ar-1 influenced the classical and alternative complement activation pathways [7].

It is likely that peptide interacts with the central complement component $-\mathrm{C} 3$, because we observed total inhibition of two complement pathways and their common point is $\mathrm{C} 3$ protein. In this study we investigated the binding of $\mathrm{Ar}-1$ with complement protein $\mathrm{C} 3 \mathrm{~b}$, the fragment of activated $\mathrm{C} 3$ protein.

Material and methods. The data about the interaction of C3b with Ar-1 were obtained utilizing surface plasmon resonance (SPR) on Biacore ${ }^{\mathrm{TM}} \mathrm{X} 100$. The series of experiments were performed on CM4 sensor chip with C3b upon addition of Ar-1 (7.8-500 nM) to the analytical cells. We calculated some models of C3c fragment and Ar-1 interaction using methods for molecular docking (Rosetta, FlexPepDock algorithm) and molecular dynamics (AMBER).

Results and discussion. We obtained the data from SPR analisys that describe heterogeneous ligand binding. It might mean that there are two types of interaction sites with high affinity $\left(K_{d}=7 \mathrm{nM}\right)$ and with low affinity $\left(K_{d}=92 \mu \mathrm{M}\right)$.

We also calculated some models of $\mathrm{C} 3 \mathrm{c}$ fragment (Chain D (328-535), PDB ID: 2qki) and Ar-1 


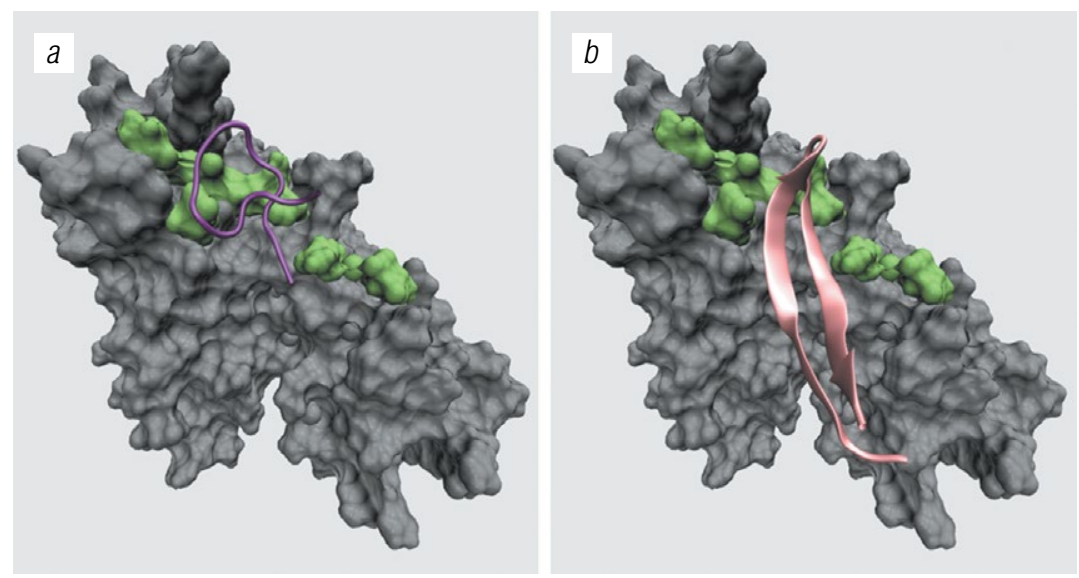

Fig. 1. Structure of C3c fragment (chain D 328-535) with compstatin (PDB ID: 2qki) (a) and with Ar-1 after $300 \mathrm{~ns}$ molecular dynamics simulation (AMBER, ff14SB) $(b)$. The residues that form hydrogen or salty bridges with Ar-1 are shown

interaction. It appeared that there are some common sites on $\mathrm{C} 3 \mathrm{c}$ fragment for compstatin, welldescribed peptide inhibitor of $\mathrm{C} 3$, and Ar-1 binding (Fig. 1). C3c (Chain D 328-535) - Ar-1 complex is stabilized by hydrogen bonds and salt bridges.

These facts should be examined carefully to construct peptide molecules derived from these
AMPs that will have strong modulatory properties depending not only the concentration but also other important parameters. The advantage of this kind of molecules is in their relative stability that is also very important for the design of new complement regulators for treating complementrelated diseases.

\section{References}

1. Panyutich AV, Szolda $\mathrm{OH}$, Peon $\mathrm{PH}$, et al. Identification of defensin binding to $\mathrm{C} 1$ complement. FEBS Lett. 1994;356:169-173.

2. Van den Berg RH, Faber-Krol MC, van Wetering S, et al. Inhibition of activation of the classical pathway of complement by human neutrophil defensins. Blood. 1998;92:3898-3903.

3. Groeneveld TWL, Ramwadhdoebe TH, Trouw LA, et al. Human neutrophil peptide-1 inhibits both the classical and the lectin pathway of complement activation. Mol. Immunol. 2007;44:3608-3614.

4. Bhat S, Song Y-H, Lawyer C, Milner SM. Modulation of the complement system by human beta-defensin 2. J. Burns Wounds. Open Science Co. 2007;5:e10.

5. Chen J, Xu XM, Underhill CB, et al. Tachyplesin activates the classic complement pathway to kill tumor cells. Cancer Res. 2005;65:4614-4622.

6. Berlov MN, Umnyakova ES, Leonova TS, et al. Interaction of arenicin-1 with C1q protein. Russ J Bioorgan Chem. 2015;41:597-601.

7. Umnyakova ES, Gorbunov NP, Zhakhov AV, et al. Modulation of human complement system by antimicrobial peptide arenicin-1 from Arenicola marina. Marine Drugs. 2018;16:e480. 